\title{
Social role for the African American males: behavioral health issues of the victim and the victimizer
}

\author{
Horton $\mathbf{A}^{*}$ \\ Lewis University and Advisory Board Governors State University, Illinois, USA
}

\begin{abstract}
Drugs and Violence in Black America: What Can Be Done?Nationally, 55 percent of black men live below the poverty level. In Chicago, 21 percent don't work, and 20 percent have less than a high school diploma.It's not an ideal picture; the street culture entailing the distribution ofillicit drugs, robbery and black on black violence as one manifestation of that harsh environment in the inner city of urban America.
\end{abstract}

\section{Introduction}

Some of the trends in the African American community have persisted over recent decades. Many inner-city communities have been further marginalized with few internal systems of accountability. The role of black middle-class people in the community has changed. In the past, poorer, less educated black who could benefit from their counsel and modeling of success, at least in theory. Today, middle class blacks often live apart from poor blacks.At best, they provide professional services (medical, educational, counseling and law enforcement) to poor blacks directly in inner-city locations or through mediated circumstances such as the media. The community-stabilizing and leadership roles do not exist in low income black neighbor hoods. In addition, large segments of the black low-income population question the legitimacy of middle class goals and aspirations. The influence of indigenous institution (such as the church which historically provided stability and counseling and a response to those in need have been undermined and made less relevant. Today, social services are provided by primarily by government and private agencies. The void created by the departure of the black middle class and reduced influence of the black church is filled by drug dealers, gangs, and various aspect of the gambling (including government sponsored lottery. When an individual is concerned about the alcohol or other drug use of a family member, there is frequently little trust in outside resources available to the family. The family often views treatment as culturally insensitive and more important as generally ineffective. Frequently, those who fail in treatment return to the community or those with other recidivist patterns (incarceration) serve as negative role models while criticizing the legitimacy of alcohol and drug treatment program. This often was the pattern for black veteran of the Viet Nam era affected by alcohol and drug use.

According to Amos N. Wilson, criminality may heuristically be perceived as a sociological symptom of a society not unlike an obsessive-compulsive disorder discussed by Freud as a psychological symptom. He goes on to state, "it may furthermore be perceived, in the classical Freudian sense, as a maladaptive comprise between two or more conflicting forces within a societal personality which have not yet been fully integrated......Symptomatic criminality while reflective of the societal, is incarnated and actualized in the minds and bodies of its individuals and group constituents. It is emblematic of the societal misallocation of power, energy, and resources; of societal hypocrisy; of as societal refusal to know itself and be true to its reality and possibilities. Criminality, as symptom, is inherently two-faced. It serves two masters. It is a double-agent, both serving and betraying."

Thus, according to, Wilson "Psychoanalytically speaking, criminality as a societal neurotic symptom does not necessarily affect all segments of a society in the same way. For some there are gains, both primary and secondary. The criminal activities of one or more segments of a society may be used by other segments to achieve identity, dominance, wealth and prestige.

These dominant societal segments, classes, or groups are often born and bred of the process of repression and impoverishment of the alienated, 'criminal' segments or constituents in their social domain. Addicted to the advantages derived from their oppression of the alienated groups, the dominant groups come to depend, whether consciously or unconsciously acknowledged, on such repressive process as necessary to their continuing relatively peaceful and profitable existence. Their dominance and advantages more often than not, rest on the deprivational subordination of the other societal elements [1].

\section{Drug crisis in America: The double standard}

America's response to the crisis was harsh, as Congress passed tougher sentencing laws aimed at punishing drug users and drug pushers alike.But now that the problem of drug addiction has moved from poor neighborhoods to middle class America in the form of opioid painkillers, there's a very different tone.Behavior that was once considered a moral failing is now being cast as a "national emergency" with the bulk of the blame being placed on the medical profession.On Wednesday (12/28/2017), Cook County officials in the state of Illinois as other suburban counties jumped on that bandwagon and filed a

Correspondence to: Arthur Horton, Ph.D, LCSW and MHS, Lewis Universityand Advisory Board Governors State University, Illinois, USA, E-mail:ahorton5201@ gmail.com

Received: January 08, 2018; Accepted: January 23, 2018; Published: January 26, 2018 
lawsuit against the nation's leading pharmaceutical companies over their "aggressive marketing of prescription opioid painkillers."'We must act in the public interest and hold accountable those who have been complicit in the creation of this epidemic," Cook County State's Attorney Kim Foxx said.The county wants pharmaceutical companies to pay for, among other things, the cost of opioid treatment and prevention programs at Cook County Jail, and for the cost of treating patients at the county's health system who overdose on opioids.That's a far cry from the mockery and the scorn heaped on crack addicts decades ago, and even these days.Does this change in attitude reflect a deeper understanding of drug addiction, or are we more compassionate because this drug crisis has been viewed as a predominantly white, suburban epidemic?Either way, the mischaracterization of the opioid epidemic has apparently put black people at an even greater risk for overdosing.

A recent report by the Chicago Urban League, "Whitewashed: The African American Opioid Epidemic" found that while AfricanAmericans make up 32 percent of Chicago's population, they accounted for 48 percent of opioid deaths."African-Americans are dying from opioid overdose at a rate higher than the general population in several states, including Illinois, Wisconsin, Missouri, Minnesota, West Virginia and in Washington, D.C.," according to the executive summary.A news website, Vox, has reported "Black Americans are now dying from overdoses at around the same rate as white Americans were in 2014."Vox came to a shocking conclusion about why the opioid painkiller epidemic initially hit white Americans much harder than black Americans. "Studies show that doctors have generally been more reluctant to prescribe painkillers to minorities, because doctors mistakenly believe that minority patients feel less pain or are more likely to misuse and sell the drugs," Vox reported.Doctors who held such prejudiced notions might have actually done their minority patients a favor.Still, it is appalling that anyone charged with providing health care could be that racist.It would be just as racist for policymakers to ignore that fentanyl-laced heroin is putting a lot of black lives at risk.

The Centers for Disease Control and Prevention reported in 2016 that fentanyl was detected in 56.3 percent of 5,152 opioid overdose deaths in 10 states that included Wisconsin and Ohio.In its first report illustrating the deaths along geographic and racial lines, the CDC also found that drug deaths for African-Americans in urban areas climbed 41 percent, compared to whites at 19 percent, the New York Times reported.Elected officials and policymakers can't let this crisis be just a "white problem."It is true what they say."When White America gets a cold, Black America gets pneumonia."

\section{A history of police misconduct: Chicago Police Department(CPD).}

\section{Victims of Police Shootings - Summer 2008}

(Revolution \#136, July 20, 2008)

\section{Jonathon Pinkerton, 17}

What Went Down:On the evening of June 11, Jonathon Pinkerton was hanging out with other teens and ran with them when police approached. Police chased Jonathan, shot him in the back-then, while he was lying on the ground wounded, one cop knelt on his back while, according to witnesses, and another cop kicked him in the head. Police claim he confronted them with a gun. Sharon Burton, Jonathon's mother, denied that her son was armed. Jonathan, paralyzed from the waist down by the police bullet, turned 17 in the hospital.
Who He Was:Seventeen-year-old Jonathan Pinkerton was a good student at Corliss High School and was planning on touring colleges this summer, between his junior and senior years. On June 11 graduation and the prom were over and he was passing a warm summer evening with his friends at Altgeld Gardens housing project. Though his mother had moved out of the "the Gardens," his grandmother still lived there. And Jonathan often returned there to spend time with the friends he grew up with.

Jonathon Pinkerton had no police record. This stands out because in the ghettos and barrios of Chicago, and across the country, many youths are scooped up into the juvenile "justice" system at a very young age. Jonathon's uncle told Revolution that in the neighborhood where Jonathon was shot, youth are frequently arrested for as little as just being outside. People in the neighborhoods of Chicago told Revolution that police routinely stop and harass young people just for wearing white t-shirts, which are very commonly worn among youth.

\section{Devon Young, 25}

What Went Down:On June 14, Chicago police shot and killed Devon Young. Neighbors say that Devon-D-Mack to people on the block-was killed, shot in the back-execution style, while kneeling with his hands in the air shouting out to the police "don't shoot, don't shoot-I ain't got nothing." The police "slapped palms" after D-Mack was killed and told each other "Good job," according to a number of people on the block who spoke with reporters. A neighbor was quoted in the Chicago Tribune saying that Young was not carrying a gun on the night he was shot and killed by police, at the age of 25 .

Who He Was:Devon dreamed of being a rap artist and practiced his raps in his friend's apartment, 40 paces from where he was killed by police. Devon's family says he was trying to get back into school and looking for work. His main goal was to be a good father to his fouryear-old son. On the block where D-Mack was killed, youth wear grim faces as they talk about how police "hop out on you for nothing." The medical examiner concluded that he died of a gunshot wound to the back. "They don't treat dogs this bad," said one of D-Mack's friends.

\section{Steven Suber}

What Went Down:On that same night, June 14, a block away from where Devon Young was shot, another young man was shot in the back after he stopped and put his hands up when the police shouted "freeze." He is now on the hospital tier of Cook County jail-also charged with possessing a weapon that his friends told us he did not have. Steven had recently attended his son's kindergarten graduation.

\section{Reginald Knight, 24}

What Went Down:On June 15 Reginald Knight was shot eight times in the back and killed by police inside his home on the South Side of Chicago. The mother of his three children was arrested when she came to the scene of the shooting around 10 or 11 at night. She was released six hours later without being charged-it was then that she learned Reginald was dead. Police claim that Knight pointed a gun at them as they chased him, but a man who says he witnessed the shooting from his porch told a Chicago TV reporter, "I didn't see no gun. He had to use both hands to get over the fence. I didn't see no gun."

Who He Was:Queen Sister of the "It Takes a Village Organization" told us that Reginald, dead at 24, will never again play the sax she said he loved so much for his church or to the children he provided for. 


\section{Melvin Barlow}

What Went Down:On June 16, according to a report in the Chicago Tribune, yet another young man was shot by police on Chicago's West Side. The article entitled " 2 killed, 3 injured in police shootings over the past week" said this man was shot and wounded by police-the fifth in a five-day span. People in the neighborhood say the victim of this police shooting, who the Tribune did not even see fit to identify, was named Melvin Barlow. Someone who lives where the shooting happened told us that the police had stopped a car, the three guys in the car broke out running, and the police shot one young Black man in the back.

\section{Luis Colon, 18}

What Went Down:Luis was shot and killed by police on a sunny day across the street from a park crowded with children. Police were on a gang suppression mission at the time, and they said when Colon was ordered to stop, he pulled out a .357-caliber Ruger handgun. Officers claim that he threatened them with the handgun. Witnesses say that Colon had a gun but was attempting to surrender when he was shot. Police sources said Colon was wearing an electronic home monitoring ankle bracelet as a condition of his parole, that he had another prior weapons conviction and was a member of the Spanish Cobras, the principal gang in the neighborhood.

Who He Was:According to family friends, Luis Colon was really into music-he especially liked to rap. He'd even made a homemade $\mathrm{CD}$, covering other rappers. He also enjoyed kickboxing. When he was ten, he had wanted to be a fireman. A family friend remembers him running around in his fireman's hat. People remember him as polite and respectful to family and friends. He loved his grandmother's home cooked Puerto Rican food. People described him as very loyal. There are four MySpace pages devoted to him: "RIP Luis Colon 6-24-08." He had just turned 18 on May 20.

\section{Darius Nicholson, 49}

What Went Down:Darius Nicholson, 49, was shot and killed by police in the bedroom of his home June 22, 2008. Callie Cooks, Darius Nicholson's wife told Chicago Channel 2 news reporters that she called police to the home she shared with Nicholson after he suddenly became violent with her. She said that something was completely out of character for the normally loving father and grandfather. "They came on a domestic. We ended up with a death," Ms. Cooks told Channel 2. "If I only knew what went on in that room that precipitated them to fire that many shots into a room with one man," said Ms. Cooks. "The situation just wasn't handled the way it could've been, and we could've had a different outcome."

\section{Robin Johnson, 44}

What Went Down:According to the police story, Ms. Johnson was allegedly in a fight with another passenger on a bus on the city's North Side when the bus driver flagged down a police officer for help. According to police, Johnson took the officer's gun in a scuffle and then shot him multiple times, resulting in his death. She was then shot multiple times by other members of the CPD as they arrived on the scene. The Sun-Times reported that her daughters challenged this story, asking how she could have overpowered the officer and noting that "she hardly knew how to use a cell phone." Johnson could now face the death penalty resulting from the charges from this incident.

Who She Was:Forty-four-year-old Robin Johnson reportedly lived on the streets off and on for years, and her daughters told the Chicago
Sun-Times that she's suffered from mental problems since an early age, as well as epilepsy. Her daughters also said that she was very sweet, enjoyed playing cards, and made sure they knew how much it meant to her that they live better lives and were able to achieve more than she had in life.

\section{Shapell Terrell, 39}

What Went Down:On the night of June 22, according to witnesses, he turned his back on detectives and opened the door to the four-flat where his mother and other members of his family stayed. "The police officer shined a spotlight on him, asked him to turn around," said Denise Franklin, Terrell's cousin. "He told them he was busy and he'll turn around he'll be done, or something like that. The police opened fire on my cousin like he was a dog running in the streetand killed my cousin right in front of his children." (Said by Denise Franklin, Terrell's cousin.) The police detectives opened fire on him, shooting him 14 times in the back. Bullet holes in the walls of the hallway six inches from the floor show how they continued to shoot him after he was lying face down in the entry hall. Shapell Terrell was shot dead by Chicago police less than a month before his 40th birthday.

Who He Was:Shepell was known as Pell or Pelly Pell to his family and friends. Shapell Terrell was raising seven children and going to work every night at 2:00 am, driving a sanitation truck. His children ranged in age from 20 years to 4 years, and his love of children showed in his special devotion to his two youngest daughters-four and five years old. His cousin described how Pell would wake up a room when he walked in with his shouts of "Whoop-de-Woop," a shout that people repeated in his honor at his funeral.

"We're supposed to be glad to see the police, but we're scared."Sharon Burton, mother of Jonathan Pinkerton, 16, who was paralyzed by a police bullet.

\section{Trends}

- All the victims in the 2008 spree were Black or Hispanic

- Most of the victims were young men

- The officers usually claim that the victim was armed but the families of the victims usually refute that claim

- In many of the cases, the victim was shot in the back, yet police claim that the victim was pointing a weapon at them. This doesn't really make sense unless the person was running while pointing the weapon backwards.

- Most of the time, what police report is different then what witnesses and neighbors claim.

- Excessive force is used. It's not necessary to shoot someone in the back 14 times while he's trying to walk inside his house.

- It is usually stated that the Internal Police Review Authority (IPRA) will conduct an investigation on the shootings, but officers rarely suffer consequences.

\section{About the internal review of police shootings}

An eight-month Chicago Tribune investigation of $200+$ police shootings going back 10 years found that within hours of a police shooting, the police department convenes hastily-assembled, wagoncircling "roundtables" of law enforcement officials where police and witnesses are questioned but not sworn or recorded, where the officers involved are allowed to confer to get their stories straight before being 
questioned, and where the inevitable conclusion is always that the shooting was justified. From there, broader, show-investigations begin. Key witnesses go un-interviewed. Forensic evidence is ignored. And the shooting officer is inevitably exonerated.

The Tribune found that even when information is later made public that contradicts the findings of internal investigations, the police refuse to reopen a case.

The Internal Police Review Authority (IPRA) was created in 2007, in the wake of highly-publicized incidents of alleged police misconduct, and findings of few citizen complaints against police were sustained. The IPRA reports directly to mayor, unlike its predecessor, the Office of Professional Standards, which reported internally to the police officials. The IPRA does take longer to investigate incidents, which Director Lana Rosenzweig [10] says is preferable to the old system where police quickly called shootings "justified."

Still, the Tribune found that even when information is later made public that contradicts the findings of internal investigations, the police refuse to reopen a case.

Wrongful death lawsuits often prompt the only full accounting of shootings and the internal investigations that follow.

In a recent suit filed by Ware's family, a veteran detective who has been the lead investigator in numerous police shootings testified that she handles too many cases to go back and re-interview officers and reconsider roundtable rulings when autopsies and other test results shed new light.

\section{"Once a case is closed, it's closed," said Sylvia VanWitzenburg.}

"Your testimony is, once you close out a [police shooting] case, no matter what new information comes in, you're not going to go back and review it?" asked the attorney representing Ware's family.

"Correct," she replied.

\section{Reactions from the Community}

Robin Hood, pastor of Redeemed Outreach Ministries in North Lawndale, believes that the increase in the fatal shootings shows that police need to forge a better relationship with the communities they serve.

Hood stressed the importance of police officers engaging youth, noting that such a relationship will lead to mutual respect and perhaps fewer police shootings.

"Police come in the neighborhood, pull an African American over, put him against the fence, either take him to jail or something happens," Hood said. "That has been the relationship for over 20 years, which has built resistance and fear in the younger people."

Jon Loevy, a civil rights attorney, said the lack of accountability within the department contributes to a culture that condones the use of excessive force.

Loevy said the police review authority was established to serve as a watchdog, but it has been ineffective. "They need different personnel," he said.

"It just seems like it's open season in our communities on our young men, whether Hispanic or African-American," said the Rev. Lewis Flowers. "I have a lot of respect for the police, but then I have a lot of respect for my community too"
Ron Hampton, executive director of the National Black Police Association and a retired officer in the Metropolitan Police Department in Washington, D.C., was surprised about the numbers. But he was most surprised about the length of time between each one. "I knew there were some police-involved shootings, but wow, what is going on up there? (Police) are not going to get anywhere with that, in terms of endearing themselves with the community," Hampton said. Hampton said it appears that the Chicago Police Department has employed military-style tactics to get a grasp on the community.

"That is destroying whatever relationship, if they ever had one, with the Black, brown and poor communities in Chicago," he said. Earlier this year, police Superintendent Jody Weis equipped scores of officers with M4 carbine assault rifles. "(Weis) needs to get a handle on it. It seems like there's a wave. There's one shooting, and then the next thing you know, there are five or six in a row. Some may be justified, but some may just be an overreaction to what's been going on," Hampton said.

He said police may have a "superficial fear" of the community. "They shoot first, then ask questions later. What the police have in their favor is shooting first. All they have to justify is stating they were in fear of their life," Hampton said. "There is no such thing as shoot to wound. They are trained to shoot to kill. They are trained to kill in the middle of person's body. All of that trying to shoot the gun out of your hand, that's cowboy stuff you see on TV," he said.

\section{Some Statistics}

- In 2008, 22 people were fatally shot by Chicago police

- Most of the victims of police shootings are African-American

- In Chicago, nearly half of the officers sued for shootings had also been sued for previous violations

- Most had been sued at least twice

- Chicago's initial "roundtable" investigations of 85 officers cleared all but one of them - and that officer got a promotion two years later.

- Chicago is one of the highest ranked cities in the nation for police shootings

\section{Possible Solutions}

When dealing with police officers that might be experiencing psychological issues, it is important to take in consideration how they behave while on duty and their interactions with others. Some common red flags that indicate psychological stress are bizarre or threatening behavior, an increase in errors while on duty, excessive absence, being on duty while intoxicated or with a hangover. This does not automatically indicate that there is a psychological issue, but it is important to take such activity in when considering a police officer's inappropriate behavior.

Research shows that officers over age of 40 had a higher 10 -year risk of a coronary event compared to average national standards; 72 percent of female officers and 43 percent of male officers, had higherthan -average cholesterol levels; and police officers as a group had higher-than -average pulse rates and diastolic blood pressure. [2-4].

"Policing is a psychologically stressful work environment filled with danger, high demands, ambiguity in work encounters, human misery and exposure to death," said Violanti, a 23- year veteran of the 
New York State Police [5]. We anticipate that data from this research will lead to police-department-centered interventions to reduce the risk of disease in this stressful occupation."

The pressures of law enforcement put officers at risk for high blood pressure, insomnia, increased levels of destructive stress hormones, heart problems, post-traumatic stress disorder (PTSD) and suicide, John M. Violanti, $\mathrm{PhD}$, research associate professor at the University at Buffalo Department of Social and Preventive Medicine in the School of Public Health and Health Professions and colleagues have found through a decade of studies of police officers. Finally, proper treatment for psychological issues and solution to impaired relations with residents of minority communities need to be taken into consideration. What can be done to protect an officer dealing with symptoms of depression? When dealing with a police officer that has Post- traumatic Stress Disorder, professional help needs to be implemented. The amount and duration will depend on the severity of the disorder [6-7]. Some social workers might also suggest participating in group therapy to hear how others are coping with the either disorder [8].

At the Macro-level or societal level Dr. Ray Hagins, African American psychologist explains how Juvenile Crime Bills--The Gang Abatement Act (2007) - target young black boys. For example, while African American youth represent only $16 \%$ of the population they are [9]:

1) $28 \%$ of Juvenile arrests,

2) $30 \%$ of referrals to juvenile court,

3) $34 \%$ of youth formally processed by juvenile court,

4) $35 \%$ of youth judicially waived to juvenile court,

5) $38 \%$ of youth in residential placement, and

6) $58 \%$ of youth admitted to State adult prison.

He claims the US government's use of the Tavis Stock Institute,a major social engineering, entity to shape social behavior in the African American community.

"To white, middle class America, childhood is supposed to be a time of learning, self-discovery, and play. Their vision, however, does not extend to all of America's youth. For many children, especially teenagersof color, their existence is met by official suspicion and repression. At school and on the streets, their activities are criminalized; a situation which is often compounded with discrimination in the juvenile justice system. Although the sum of these social forces is the disruption of entire communities and perpetuation of racial disparities, political inertia, media distortions, racism and structural limitations of America's post- industrial economy are blocks to important reforms."

From my perspective, the most recent effort to reduce gang- related activities does not focus on prevention with only minimal funding and as critics appropriately argue is not predicated on evidence-based interventions. Additionally, there are deeper issues that have to be confronted.

Illinois leads the nation in per-capita gang members, and Chicago is the only city in the United States to rank in the top five in distribution for heroin, cocaine, marijuana and methamphetamine trafficked by Mexican cartels. In the city, the Chicago Police Department estimates that gangs account for $80 \%$ of all murders. Throughout Illinois, gangs are a serious problem and hold back the economic potential of our communities.

This month, January2014 a more than six-month effort to provide law enforcement, prosecutors and local communities with additional funding was signed into law.
Congress boosted resources to fight "gangs of national significance" with a total price tag of $\$ 18.5$ million. This money will be used to combat gangs such as the Gangster Disciples.

Such efforts probably will have minimal impact The American family is the first conditioning agency for the mode of self -identity that to leads aggression. The boys learn very early that if he is to attain real manhood, he must perform and compete much better than girls. To be thought as a "sissy or wimp" is tragic to a male child. By way of toys and games (particularly electronic versions) he is schooled to muscular and psychic aggressiveness. He understands from the start that both his own identity and society's acceptance of him as a man depends on his being dominant toward and protective of females and successfully competitive toward other males. This becomes more of a challenge to the male since of self esteem if he most competes with women in the work world or military/Para-military entities (policing jobs at the municipal, county or state levels.

The American family also teaches the violence by direct example, notably father - mother relations. Overt violence on the part of the husbands toward their wives, while not common, is sizable social reality.

In addition to wife-beating there are threats of abandonment, which are especially menacing to women whose socialization has left her without independent means of support. Furthermore, she may be punished or ignored or by having her movement and her circle of friends limited. The young boy observes these control patterns and incorporates them into his own personality for personal use. Again, he sees his father has all the power while his mother is weak and submissive. This experience also creates in him a potentially destructive, aggressive person. He may value the unconditional love of the mother and at the same time reject or even despise her for derivative and dependent status. Later, his owns desires for status and adventure may cause him to suppress the affectional dimension in himself to seek power among males.

At the same time, women's resentment at being used gives rise in them to feelings of hostility which may prompt them to manipulate their husbands in devious ways and to exercise over their children a dominance that harms the latter psychologically. These are hidden structures of animosity in family life. Rising from the sexist structure of American culture, create a climate of enmity, envy, and suspicion, a training ground for violence.

For in such a climate, the roles and expectations of family members degenerate so that none of them can realize personal potential, much less empower others. Feeling psychologically impotent, they lack a sense of self worth. And psychological and sociological studies have shown, low self- regard tends to lead to aggressive behavior.

What the family began is reinforced in more sophisticated ways in schools. Athletic events, academic grades, examinations are geared to fashion males children into competitors and achievers. Of course, competitiveness does not necessarily conduce to violence. It may be just a rivalry that makes that makes the contest an enjoyable exercise or display of skills. But many schools particularly at the collegiate indoctrinate the young male with a deadly serious spirit of aggression. $\mathrm{He}$ is trained for a confrontation with others in which his own selfidentity, self-respect and public acceptance are at stake. He can hardly lose. Winning is everything, even if it means trampling on his fellows. Hostility and violence are tools for removing obstacles on the way to the top. More perhaps than formal schooling, the young male is influenced by peer relationships. Here again a sexist mentality is basic, 
though it reveals itself in different ways. Among deprived minority groups for instance, the gang offers the young male a quick road to personal selfhood and social respect in his own group and even in the larger society (gangster rap as an example) that has stacked the deck against him and his peers. A tough stance and acts of violence brings material rewards, a reputation for bravery, and the adulation of some females. For in the gangs, the woman's role is essentially subordinate and derivative;she functions to bolster male toughness and sexual inclinations. The gang reflects in crude miniature fashion some of the impulses that drive the American society. It is a chapter in the long national history of aggressive individualism, frontier lawlessness and the glorification of lawlessness

Violent crime in the United States is a particularly male phenomenon as further evidenced in domestic violence and rape statistics. The young male torn by doubt about his own sexual capacity, flees from the specter of homosexuality and reassures himself in violent sexual activity. The problem is not that most young male are quite naturally somewhat insecure sexually; rather, it is the domineering, violence -related sexuality that is advocated as the cure. Going into law enforcement for some males may provide a means to repress threatening sexual impulses.

\section{Strategic Gentrification}

Democratic governor candidate (Illinois) Chris Kennedy son of the late Robert Kennedy on Wednesday (1/4/2018) accused Mayor Rahm Emanuel (Chicago)of leading a "strategic gentrification plan" aimed at forcing African-Americans and other minorities out of Chicago to make the city "whiter" and wealthier.

"I believe that black people are being pushed out of Chicago intentionally by a strategy that involves disinvestment in communities being implemented by the city administration, and I believe Rahm Emanuel is the head of the city administration and therefore needs to be held responsible for those outcomes," Kennedy said during a news conference about gun violence in North Lawndale.

"This is involuntary. That we're cutting off funding for schools, cutting off funding for police, allowing people to be forced to live in food deserts, closing hospitals, closing access to mental health facilities. What choice do people have but to move, to leave?" Kennedy added. "And I think that's part of a strategic gentrification plan being implemented by the city of Chicago to push people of color out of the city. The city is becoming smaller, and as it becomes smaller, it's become whiter." (Figure 1) present the significant exodus of African Americans out of Chicago. The high unemployment in the innercity neighborhoods of Chicago is not addressed by Kennedy. However, the indifference Mayor's administration is part of the problem.

\section{Conclusion}

If the issue of police violence against African-American youth and adults were to be put into an appropriate framework, the major theme could be appearance vs. reality since there is a running trend of deception. The community is deceived into thinking that the police are beneficial to society, but there is obviously some internal bias against African-Americans. The police then deceive the community by calling the shootings justified, regardless of how frequent or excessive they are. This "appearance vs. reality" theme also appears when police pull over black youth just for wearing white T-shirts or walking down the street and "looking" suspicious. There is clearly racial profiling occurring when police randomly stop people on the street for no reason. The
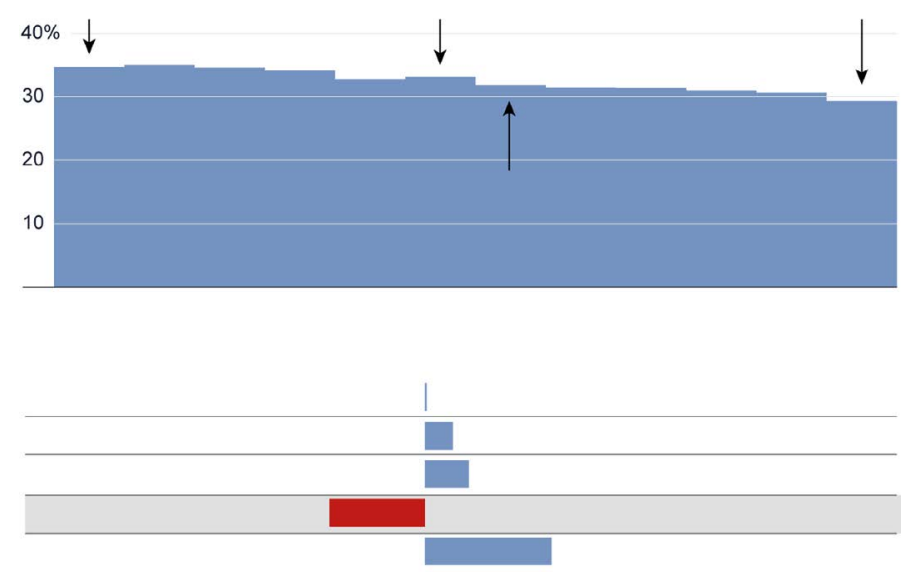

Figure 1. Represents percentage of African Americans 2005(34.7\%),2010(33.2\%) and $2016(29.3 \%)$. Represents the exodus of African Americans since $2010(-11.5 \%$ in red compared to the blue,increases in other racial and ethnic groups. (Share of black population shrinkingBlack population as a percentage of total population of Chicago).

apparent "crime" these victims committed was being Black in the city of Chicago. Could it also represent the psychological vulnerability of certain impaired police officers?

In conclusion, this not just a story of the relatively high levels of incarceration of African American males at most level of government prisons or jails in the states in which they reside nor the invisibility of elderly Black males and even those to that provide time lifethroughout their lives in civic, private and public sector in the various regions of the nation compared to their white counterparts and highly regarded highly regarded historical figures in each state ,each county and city $[10,11]$ The overall damaging consequence has been the decline of opportunity to improve one's status and a lack of African American social mobility. It also might mean that people in poor neighborhoods end up in a self reinforcing cycle of under-funded schools, high crime and social breakdown [12-17]

The AfricanAmerican community has been able to with stand historic and current social forces such as oppression and racism [18]. Cultural values that include collectivism, spiritualism, a common worldview, close ties to a glorious and ancient history of community building, along with a system of facilitating human development (rites of passages) have together supported African Americans in surviving and successfully thriving [19].

Despite what appears to be a bleak portrait of African American family life, it is also true that resilience and cultural strength has enabled members of the African American population to " to keep on keeping on." I end by quoting a resident of Hyde Park in Chicago, Illinois.

The identity theft perpetrated on the Black people is outright criminal, what is worse than that is that Black people identify themselves with a complete fabrication, a denial of who they are. The Stockholm syndrome is at play here: a people whose identity has been stolen now accept the new lie by those who did the stealing as a reality.

We should not be caught up in asking for equivalences such as "European American", we should just call ourselves Black and demand that others do the same.How can you try to save a people without true identity? There is no social study, program that can restore the stolen value, only Black people can do it by themselves (John Palla). 


\section{References}

1. Wilson AN (2011) Black on black violence: The psychodynamics of black self -annihilation in service of White Domination, African World Info Systems, New York.

2. Charles LE, Hartley TA (2008) Shift-work and suicide ideation among police officers. Am J Ind Med 51: 758-768.

3. Balko R (2007) Want to get away with murder in Chicago? Retrieved from http://www. theagitator.com/2007/12/13/want-to-get-away-with-murder-in-chicago/

4. ChaneyK(2008) Chicago's police-involved shootings among highest for big cities. Retrieved from http://news.newamericamedia.org/news/view_article.html?article_id= 05072406f36465c20de5dc0dde100af1.

5. Chicago has fifth police-involved shooting in 5 days. (2008, July 08). Retrieved from http://officer.com/publication/printer.jsp?id=41833.

6. Lum J (2008) Weis on CPD shootings: officers face danger daily. Retrieved from http:// cbs2chicago.com/local/police.involved.shootings.2.756.

7. Nine victims of police shootings in Chicago (2008) Revolution, 136. Retrieved from http://revcom.us/a/136/136-chicago_police-en.html

8. Rozas A (2008) 2 killed, 3 others wounded in Chicago police shootings.Retrieved from http://articles.chicagotribune.com/2008-06-17/news/0806160549_1_fatal-shootingchicago-police-shot-wednesday-evening.

9. Silva F, Voung L (2008) Evaluating National Gang Bills. Analysis from the National Council Crime and Delinquency

10. Sen R, Tate A (2007) Too many Police shootings: more than a few bad apples. Retrieved from http://www.sonomacountyfreepress.com/police08_toomany.html.
11. Haney C, Zimbardo D (1998) The Past and Future of U.S. Prison Policy; Twenty-Five Years After the Stanford Prison Experiment. American Psychologist 53: 716-718.

12. Mason CA, Chapman DA, Chang S, Simons J (2003) Impacting re-arrest rates among youth sentenced in adult Court: An epidemiological examination of the juvenile sentencing advocacy project. Journal of Clinical Child \& Adolescent Psychology 32: 205-214

13. HortonA (2013) African American male drug use and gambling and criminal behavior, the need for more effective treatment. The Journal of Alcohol and Drug Dependence $1: 1-3$

14. HortonA (2007) Murder in the City; embedded, intractable, and treatment resistant. The Journal of Human Behavior in the Environmnent 16: 15-29.

15. Horton A (2002) Violent crimes and racial profiling: What the evidence suggests. The Journal of Human Behavior in the Social Environment 6: 87-106.

16. Welch R, Angulo CT (2000) Justice on trial: Racial disparities in the American justice system Washington: DC: Leadership Conference on Civil Rights/ Leadership Conference on Education Funds, May 2000).

17. Sue DW (2010) Microagressions in everyday life: race, gender, and sexual orientation. Hoboken, NJ: John Wiley \& Sons.

18. HillP(1992)Coming of Age: African American Male Rites of Passages, Chicago, IL: Africa America Images.

19. Thomas MC, Vines DNL (2010) Culturally competent collaboration: school counselor collaboration with African American families and communities. Professional School Counseling 14: 53-63.

Copyright: (C2018 Horton A. This is an open-access article distributed under the terms of the Creative Commons Attribution License, which permits unrestricted use, distribution, and reproduction in any medium, provided the original author and source are credited. 